Research Article

\title{
Competitive Ability of Wheat Crop against Different Densities of Avena fatua and Silybum marianum
}

\author{
Ijaz Ahmad* and Bakhtiar Gul
}

Department of Weed Science and Botany, Faculty of Crop Protection Sciences, The University of Agriculture, Peshawar, Khyber Pakbtunkhwa, Pakistan.

\begin{tabular}{|c|c|}
\hline \multicolumn{2}{|r|}{$\begin{array}{l}\text { weeds of the wheat crop in Pakistan. Four treatments viz. wheat, wheat }+S \text {. mariant } \\
\text { S. marianum and } A \text {. fatua were examined to check their effect on the growth dynar } \\
\text { and replicated thrice. The results showed that all the wheat growth parameters } \\
\text { by the weeds competition in both the studied years. The maximum wheat plant } h \\
\text { recorded in wheat, having no weeds competition during the year } 2018 \text { and } 2019 \\
\text { minimum plant height (cm) } 30.4 \text { and } 31.9 \text { was recorded in wheat infested with } \\
\text { marianum. Due to the large leaf canopy of } S \text {. marianum, it is not possible for other } \\
\text { several broadleaf weeds are highly competitive and make a high canopy over the } \\
\text { photosynthesis and the morphological mimicry of } A \text {. fatua with wheat crop during t } \\
\text { It cannot be easily distinguished from wheat seedlings. Results showed that whea } \\
\text { had maximum biomass, and leaf area index in both the growing season as compan } \\
S . \text { Marianum) infested wheat. Therefore, management of these weeds i.e., } A \text {. fatua }\end{array}$} \\
\hline & $\begin{array}{l}\text { Received | December 22, 2020; Accepted | March 21, 2021; Published | June } 01,2021 \\
\text { "Correspondence | Ijaz Ahmad, Department of Weed Science and Botany, Faculty of Crop Protection Sciences, The University of Agriculture, } \\
\text { Peshawar, Khyber Pakhtunkhwa, Pakistan; Email: ijazws@aup.edu.pk } \\
\text { Citation | Ahmad, I. and B. Gul. 2021. Competitive ability of wheat crop against different densities of Avena fatua and Silybum marianum. Sarbad } \\
\text { Journal of Agriculture, 37(2): 631-638. } \\
\text { DOI | http://dx.doi.org/10.17582/journal.sja/2021/37.2.631.638 } \\
\text { Keywords | Avena fatua, Densities, Silybum marianum, Wheat crop, Weed management }\end{array}$ \\
\hline
\end{tabular}

\section{Introduction}

W ith increasing population growth, there is a growing interest in maximizing crop yield to fulfill food, feed, and fiber requirements. However, weeds represent a threat to secure this goal as they compete with crops for nutrients, moisture, space, and sunlight which result in the reduction of yield (Khan et al., 2004). In Pakistan, wheat contributes around $10.3 \%$ to agricultural production and $2.2 \%$ to GDP and is planted on more than 9 million hectares and an annual production of more than 25 million tons (Anonymous, 2014, 2016). In the year 2000, wheat yield losses due to weed competition amount to more than Rs. 28 billion in the whole country and Rs. 2 billion in the province of Khyber Pakhtunkhwa (Hassan and Marwat, 2001).

Avena fatua L (wild oat) in Pakistan, is a summer annual grassy weed that represents a serious threat 
to spring wheat farmers across the world (Hassan and Marwat, 2001). Its competitive-ability and vigorous early growth suppress wheat emergence and growth. Also, A. fatua early seed maturity and efficient seed dispersal mechanisms further increase its noxiousness (Khan et al., 2012). A. fatua impact on wheat occur not only during the early growing period but may continue until the maturity of the crop up. However, the highest yield loses in wheat occurs before 45 to 50 days of wheat sowing (Khan et al., 2008, 2012) determined that the wheat yield is reduced exponentially when wild oat density increases from 0 to 30 plants $\mathrm{m}^{-2}$. Similarly, wild oat reduced a number of tillers in various wheat cultivars (Khan et al., 2010). However, apart from density, the time of weed germination and emergence in the field is influenced by light, soil temperature, soil moisture, and soil atmosphere (Shaheen et al., 2016).

S. marianum L (Holy thistle) is one of the most troublesome weed species in the wheat in irrigated districts of North-West Pakistan (Darwent et al., 2006) determined that 15 to 20 shoots $\mathrm{m}^{-2}$ of $S$. marianum can reduce the wheat yields up to $36 \%$. The conventional and reliable weed management strategies for Holy thistle cannot be executed without a clear understanding of inter-specific competition in $S$. marianum and primary winter crops (Khan and Marwat, 2006; Umm-E-Kulsoom et al., 2020).

Numerous works have been done to evaluate $A$. fatua and $S$. marianum competitive impact on wheat (O Donovan et al., 2000; Korres et al., 2002; Khan et al., 2006; Lehnhoff et al., 2013). However, to our knowledge, no research has evaluated the combined effect of these two species on wheat. Large numbers of studies have been documented on weeds competition and density of wheat crop for improving growth and yields. Numerous works have been done on wild oat and holy thistle competition too, individually with the wheat crop. Though, there is no literature available on the combined effect of broadleaf and grassy (Silybum marianum L. and Avena fatua L.) weed competition with wheat. The purpose of this study will help to examine both the broadleaf and grassy weeds competition with the following objectives.

- To determine the effect of varying densities of Silybum marianum and Avena fatua on the wheat competition.

- To quantify the threshold density of these noxious weeds in wheat.
- To examines the effect of intra and inter-specific competition on the growth and development of wheat and the weeds.

\section{Materials and Methods}

A pot experiment was conducted at the Department of Weed Science, The University of Agriculture Peshawar-Pakistan in 2017-18 and 2018-19. The pots had a height of $18.79 \mathrm{~cm}$ and were $21.84 \mathrm{~cm}$ diameter each pot was filled with $5 \mathrm{~kg}$ of the soil just below the rim to accommodate the water for irrigation for seed germination and development. Atta-habib, a widely cultivated wheat variety was sown along with the $A$. fatua and $S$. marianum seeds in pots with equal distance and with the optimum soil depth for maximum germination. The experimental design was Completely Randomize Design (CRD) with three replications. All the pots were labeled as per treatment and were randomly rearranged every week to reduce any variation in sunlight and temperature. The number of total plants per pot was kept constant while the number of individual species varied according to the treatments as per the plan of work given below:

1. 4 plants of wheat per pot

2. 4 plants of Avena fatua per pot

3. 4 plants of Silybum marinum per pot

4. 2 plants of wheat and 2 Avena fatua

5. 2 plants of what and 2 Silybum marinum

6. 2 plants of Avena fatua and 2 Silybum marinum

7. 2 plant of wheat, 1 Avena fatua and 1 Silybum marinum.

No fertilizers were added to the pots and they were weekly checked to minimize the effect of microclimate and irrigation with an equal amount. The wheat and weeds were harvested after three months of sowing and the biomass of weeds and wheat was recorded separately. During the study the data was taken on the following variables:

\section{Plant height (cm)}

The plant height data was taken at physiological maturity. Plants height $(\mathrm{cm}$.) of five random plants from the base to leaves tip was recorded in each pot and then the average was computed.

Biomass of wheat $(\mathrm{gm})$

Biomass of wheat was recorded by the following formula: 
Biomass of wheat $=\frac{\text { Weight of sample }(\mathrm{g})}{\text { Area harvested }(\text { pot })}$

Biomass of Avena fatua (gm)

Biomass of Avena fatua was recorded by the following formula:

$$
\text { Biomass of Avena fatua }=\frac{\text { Weight of sample (g) }}{\text { Area harvested (pot) }}
$$

\section{Biomass of Silybum marianum (gm)}

Biomass of $S$. marianum was recorded by the following formula:

$$
\text { Biomass of S. marianum }=\frac{\text { Weight of sample (g) }}{\text { Area harvested (pot) }}
$$

\section{Leaf area index (LAI)}

Leaf area index (LAI) is a dimensionless quantity that characterizes plant canopies. It is defined as the one-sided green leaf area per unit ground surface area $\left(\mathrm{LAI}=\right.$ leaf area $/$ ground area, $\left.\mathrm{m}^{2} / \mathrm{m}^{2}\right)$ (Watson 1947).

The leaves sampling for determining leaf index was randomly collected from wheat plants in each pot and then average LAI was computed by using leaf area meter.

\section{Relative growth rate ( $g g^{-1}$ dwt day $\left.{ }^{-1}\right)$}

To record the relative growth rate, the same plants were cleaned and oven-dried at $70^{\circ} \mathrm{C}$ for 48 hours. Following formulae proposed by Gardner et al. (1985), the relative growth rate was calculated as:

$$
\text { Relative Growth Rate }=\frac{\ln W 2-\ln W 1}{\mathrm{~T} 2-\mathrm{T} 1}
$$

Where;

$\mathrm{W} 1=$ Dry weight of the first harvest; W2= Dry weight of the second harvest; $\ln =$ Natural logarithm; T2-T1=Time interval between two harvests.

Specific leaf area: $\left(\mathrm{cm}^{2} \mathrm{~g}^{-1}\right)$ was calculated according to Hunt (1990).

$$
\text { Specific Leaf Area }=\frac{\text { Leaf Area per Plant } \mathrm{m} 2 \mathrm{~g} 1}{\text { Leaf weight per plant }}
$$

Leaf area ratio: $\left(\mathrm{cm}^{2} \mathrm{~g}^{-1}\right)$. was calculated by as:
Leaf Area Ratio $=\frac{\text { Leaf area per plant }}{\text { Weight per plant }}(\mathrm{cm} 2 \mathrm{~g} 1)$

\section{Results and Discussion}

\section{Plant height (cm)}

Plant height is an important parameter that attributes to the yield of the crop. In this study, wheat height was negatively impacted by the infesting weeds (Table 1). In 2017-2018, the wheat crop grown in the absence of weeds achieved the maximum plant height $(38.1 \mathrm{~cm})$, while in competition with $A$. fatua and $S$. marianum its height was reduced to $30.4 \mathrm{~cm}$. A similar trend was observed in 2018-2019, with wheat plants growing in similar conditions achieved the maximum plant height $(39.4 \mathrm{~cm})$ but competition with $A$. fatua or $S$. marianum resulted in shorter plants $(31.9 \mathrm{~cm})$. Overall, this two-year experiment showed that wheat height is negatively affected in the presence of either of the A. fatua or S. Marianum plants.

Table 1: Wheat plant height $(\mathrm{cm})$ as affected by weeds competition.

$\begin{array}{lll}\text { Treatments } & \mathbf{2 0 1 7 - 1 8} & \mathbf{2 0 1 8 - 1 9} \\ \text { Wheat } & 38.1 \mathrm{a} & 39.4 \mathrm{a} \\ \text { Wheat }+ \text { Silybum marianum } & 33.0 \mathrm{~b} & 34.5 \mathrm{~b} \\ \begin{array}{l}\text { Wheat }+ \text { Avena fatua } \\ \text { Wheat }+ \text { Avena fatua and Silybum } \\ \text { marianum }\end{array} & 33.3 \mathrm{~b} & 34.6 \mathrm{~b} \\ \mathrm{LSD}_{0.05} & 31.9 \mathrm{c} \\ \end{array}$

In the absence of weed competition, wheat plants were able to take full advantage of the available resources such as nutrients, light, moisture, and space. The combined effect of $A$. fatua and $S$. marianum was larger than the individual impact of each of these two weed species. Both these weed species are highly efficient competitors, (Umm-E-Kulsoom et al., 2020) which resulted in reduced wheat growth, biomass, and yield underscoring the need to develop efficient weed management strategies to secure the required crop yield. This study also provides further information about the interactive competitive effects of $A$. fatua and $S$. marianum on yield losses in wheat crops. According to Khan et al. (2008), A. fatua density and competition have a significant effect on the plant height of the wheat crop. Bogale et al. (2011) also observed a reduction in plant height of wheat due to weeds competition. Similarly, Nassab and Farshad (2012) and Woldesenbet et al. (2016) observed a 
decreasing trend in the height of wheat plants when weeds were not properly managed.

\section{Wheat biomass}

Weed competition severely affected the biomass production of wheat during the two years of study. Under no competition, the mean data presented in Table 2 reported that wheat biomass was $153.3 \mathrm{~g}$ for the year 2018-19, and $143.0 \mathrm{~g}$ for 2017-18. A significant decrease in wheat biomass was observed for both years i.e. (133.7 and $144.2 \mathrm{~g}$ ), during wheat grown in the combination with $S$. marianum and $A$. fatua. Wheat is an important crop in Pakistan and weeds represent the major constraint in yield and biomass production as it is highly sensitive to weed competition at early growth stages (Weisany et al., 2016). The results showed that wheat biomass is highly sensitive to competition with weeds. The decrease in wheat biomass may be due to high weed pressure and competition for resources which causes a reduction in biomass. This research study is in line with Nassab and Farshad (2012) who reported that treatment of weed decreased the biomass of wheat. Bogale et al. (2011) investigated that weed affected the biomass of wheat. Umm-e-Kulsoom and Khan (2015) studied that weed decreased the biomass of wheat. Woldesenbet et al. (2016) reported that the biomass of wheat is affected by weed.

Table 2: Wheat biomass (gm) as affected by intra- or inter-specific competition.

\begin{tabular}{lll} 
Treatments & \multicolumn{2}{c}{ Year } \\
& $\begin{array}{l}\text { 2017-18 } \\
\text { Wheat }\end{array}$ & 2018-19 \\
Wheat + Silybum marianum & $137.0 \mathrm{a}$ & $153.3 \mathrm{a}$ \\
Wheat + Avena fatua & $148.1 \mathrm{ab}$ \\
$\begin{array}{l}\text { Wheat + Avena fatua and Silybum } \\
\text { marianum }\end{array}$ & $137.3 \mathrm{~b}$ & $148.6 \mathrm{ab}$ \\
LSD $_{0.05}$ & $5.5 \mathrm{c}$ & $144.2 \mathrm{~b}$ \\
& & $\mathrm{NS}$
\end{tabular}

\section{Biomass of Avena fatua}

Data in Table 3 reveal that that inter-and intraspecific competition severely affected $A$. fatua biomass. Results indicated that $A$. fatua when grown in monoculture, had the highest biomass production for 2018-19 (77.5g) and 2017-18 (73.7g). The results also demonstrated the relative importance of intraand inter-specific competition in determining $A$. fatua biomass. Specifically, the lowest biomass $(26.7 \mathrm{~g}$ and $30.3 \mathrm{~g}$ ) was observed when $A$. fatua has grown in combination with wheat and $S$. marianum for both years, respectively. The results are similar to Abbas et al. (2010) who reported that increasing the density of wild oat, the biomass increased. Because a greater number of plants produce more tillers and thus captures more resources which ultimately reflects in biomass accumulation. Singh et al. (2013) have shown the competitive ability of weed with wheat was density-dependent probably due to the biomass of weeds. Thus, growth could be different under different climates (Scott et al.,2016) and temperatures (Shaheen et al., 2016). The same results were also reported by (Blanco et al., 2014).

Table 3: Biomass ( $g$ ) of A. fatua as affected by intra- or inter-specific competition.

\begin{tabular}{lll} 
Treatments & \multicolumn{2}{c}{ Year } \\
& $2017-2018$ & 2018-2019 \\
Avena fatua & $73.7 \mathrm{a}$ & $77.5 \mathrm{a}$ \\
Wheat + Avena fatua & $45.3 \mathrm{~b}$ & $48.7 \mathrm{~b}$ \\
Wheat + Silybum marianum and & $26.7 \mathrm{~b}$ & $30.2 \mathrm{c}$ \\
Avena fatua & & \\
Silybum marianum and Avena fatua & $40.3 \mathrm{~b}$ & $43.7 \mathrm{~b}$ \\
LSD $_{0.05}$ & 19.57 & 19.30
\end{tabular}

\section{Biomass of S. marianum}

Data in Table 4 show that in 2017-18 and 2018-19, $S$. marianum biomass was differently impacted by intraand interspecific competition. For both years, the maximum biomass was observed when $S$. marianum was grown in monospecific conditions $(32.3 \mathrm{~g}$ and $36.0 \mathrm{~g}$, respectively) and the lowest biomass was observed when it grew in combination with wheat and $A$. fatua ( $8.7 \mathrm{~g}$ and $11.9 \mathrm{~g}$, respectively). Biomass is the basic parameter and showed the adaptation strategy of any plant in their environment. Biomass is the phenotypic characteristics of plants and showed the healthy status of plants and vice versa. This result showed that due to inter and intraspecific competition, the biomass production of $S$. marianum was also significantly affected and also showed that $S$. marianum in competition loss its status as compared to alone. Previous work has also evaluated the relative importance of intra- and inter-specific competition in determining weed biomass. Our results are similar to Khan et al. (2008) that reported that weed biomass reduced with combination with wheat. Similarly, Abdullah et al. (2008) reported that agronomic traits of maize (Zea mays) significantly affected weed biomass. Marwat et al. (2011) studied that wheat 
affected the biomass of weed. Fakhari et al. (2018) studied that the combination of wheat and rye affects the biomass of weed.

Table 4: Biomass (g) of S. marianum as affected by intraand interspecific competition.

\begin{tabular}{|c|c|c|}
\hline \multirow[t]{2}{*}{ Treatments } & \multicolumn{2}{|c|}{ Year } \\
\hline & 2017-2018 & 2018-2019 \\
\hline Silybum marianum & $32.3 \mathrm{a}$ & $36.0 \mathrm{a}$ \\
\hline Wheat + Silybum marianum. & $16.0 \mathrm{~b}$ & $19.5 b$ \\
\hline $\begin{array}{l}\text { Wheat }+ \text { Silybum marianum and } \\
\text { Avena fatua }\end{array}$ & $8.7 \mathrm{c}$ & $11.9 \mathrm{c}$ \\
\hline Avena fatua + Silybum marianum & $15.0 \mathrm{~b}$ & $19.0 \mathrm{~b}$ \\
\hline $\mathrm{LSD}_{0.05}$ & 12.37 & 12.47 \\
\hline
\end{tabular}

Table 5: Leaf area index of wheat crop as affected by density of weeds.

\begin{tabular}{lll} 
Treatments & \multicolumn{2}{c}{ Year } \\
& $2017-2018$ & $2018-2019$ \\
Wheat & $3.1 \mathrm{a}$ & $3.2 \mathrm{a}$ \\
Wheat + Silybum marianum & $2.6 \mathrm{~b}$ & $2.7 \mathrm{~b}$ \\
Wheat + Avena fatua & $2.6 \mathrm{~b}$ & $2.7 \mathrm{~b}$ \\
Wheat + Silybum marianum and & $2.3 \mathrm{c}$ & $2.4 \mathrm{c}$ \\
$\begin{array}{l}\text { Avena fatua } \\
\text { LSD }_{0.05}\end{array}$ & 0.20 & 0.20
\end{tabular}

\section{Leaf area index $(\mathrm{cm})$}

Data in Table 5 showed that weed competition significantly affected the leaf area index. Specifically, when growing in monocultures, the maximum leaf area was recorded (3.1 and 3.2 for 2017-18 and 201819 , respectively) and the minimum leaf area index was recorded when the wheat is grown in combination with A. fatua and S. marianum (2.3 and 2.4, respectively). Our results suggest that the reduction in leaf area of wheat crop may be due to competition it is experienced when growing in combination with $S$. marianum and $A$. fatua. Several broadleaf weeds are highly competitive and make a high canopy over the crop to get more light for photosynthesis (Khaliq et al., 2012). The effect of broadleaf weed is more pronounced in affecting the leaf area index and in the absence of broadleaf weed increase the survival and competition potential of crop achieved more leaf area index that reached to 3.2. Our research is in line with Khan et al. (2005) who determined that the leaf area index showed significant results. Khan et al. (2008) studied that the leaf area index of wheat was significantly affected by weeds. Nassab and Farshad
(2012) revealed that weed affected the leaf area index of wheat. Ziaf et al. (2009) also investigated the leaf area index of wheat was affected by weed.

\section{Relative growth rate $\left(g g^{-1} d w t\right.$ day $\left.y^{-1}\right)$}

Data in Table 6 reveal that $S$. marianum and $A$. fatua had significantly affected Relative growth rate. This study indicated that the relative growth rate of wheat was similarly impacted by inter and intra specific competition during both years of 2017-18 and 201819 . The results showed that growth in monocultures wheat relative growth was statistically at par for both the consecutive years 2017-18 and 2018-19. Therefore, this study indicates that wheat's relative growth rate is not sensitive to different competitive conditions. Some authors have reported a significant response of wheat to different densities (Khan et al., 2005; Kumar et al., 2012; Zaif et al., 2009).

Table 6: Relative growth rate of the wheat crop as affected by density of weeds.

\begin{tabular}{lll} 
Treatments & \multicolumn{2}{c}{ Year } \\
& 2017-2018 & 2018-2019 \\
Wheat & $0.02 \mathrm{a}$ & $0.036 \mathrm{a}$ \\
Wheat + Silybum marianum & $0.019 \mathrm{a}$ & $0.035 \mathrm{a}$ \\
Wheat + Avena fatua & $0.019 \mathrm{a}$ & $0.036 \mathrm{a}$ \\
$\begin{array}{l}\text { Wheat + Silybum marianum and } \\
\text { Avena fatua }\end{array}$ & $0.019 \mathrm{a}$ & $0.034 \mathrm{a}$ \\
LSD $_{0.05}$ & $\mathrm{NS}$ & $\mathrm{NS}$
\end{tabular}

\section{Specific leaf area $\left(\mathrm{cm}^{2} \mathrm{~g}^{-1}\right)$}

Data regarding specific leaf area in Table 7 indicated that wheat growing in monospecific conditions recorded maximum specific leaf area (279.3 and 280.5, for 2017-18 and 2018-19, respectively) as compared with wheat growing in combination with $A$. fatua and S. marianum. Specifically, wheat in competition with $S$. marianum and $A$. fatua reduced the specific leaf area and recorded a minimum leaf area in both years. The specific leaf area was slightly greater in the year 2018-19 than the specific leaf area of 2017-18 which might be due to environmental fluctuations. These results revealed that a specific leaf area is a sensitive parameter to the competition. Both weeds have a highly competitive ability against wheat causing in a reduction of specific leaf areas. These results are in confirmation with Zaif et al. (2009) who reported that specific leaf area was reduced when different treatments were applied. 
Table 7: Specific leaf area of the wheat crop as affected by density of weeds.

\begin{tabular}{lll} 
Treatments & \multicolumn{2}{c}{ Year } \\
Wheat & 2017-2018 & 2018-2019 \\
Wheat $+S$. Marianum & $279.3 \mathrm{a}$ & $280.5 \mathrm{a}$ \\
Wheat + A. fatua & $244.1 \mathrm{~b}$ & $245.1 \mathrm{~b}$ \\
Wheat + S. marianum and $A$. fatua & $225.4 \mathrm{c}$ & $226.4 \mathrm{c}$ \\
LSD $_{0.05}$ & 12.04 & 11.99
\end{tabular}

\section{Leaf area ratio $\left(\mathrm{cm}^{2} \mathrm{~g}^{-1}\right)$}

Data regarding leaf area ratio presented in the Table 8 exhibit that competition of $A$. fatua and $S$. Marianum with wheat had a significant effect on leaf area ratio. Statistical analysis revealed that interspecific competition with $A$. fatua and $S$. Marianum resulted in a reduction in the leaf area ratio of wheat. The maximum leaf area ratio (216 and 218, for 201718 and 2018-19, respectively) when wheat crop was grown in monospecific conditions. However, a decline in leaf area ratio was observed when wheat grew in combination with both $A$. fatua and $S$. marianum, and recorded minimum values (174.3 and 176.3, for 201718 and 2018-19, respectively). These results suggest that decreased weed crop competition increased leaf size is an attempt to maximize the light interception and increase the wheat economy for gaining of resources needed for growth and development. These results are in confirmation with Zaif et al. (2009) who observed that leaf area ratio was significantly reduced under different treatment. Our research is in contrast with Amanullah et al. (2007) LAR improved to a maximum with increasing plant density. Medek et al. (2007) observed that leaf area ratio was positively correlated with the relative growth rate.

Table 8: Leaf area ratio of the wheat crop as affected by density of weeds.

\begin{tabular}{lll} 
Treatments & \multicolumn{2}{c}{ Year } \\
& 2017-2018 & 2018-2019 \\
Wheat & $216.0 \mathrm{a}$ & $218.0 \mathrm{a}$ \\
Wheat + Silybum marianum & $189.5 \mathrm{~b}$ & $191.3 \mathrm{~b}$ \\
Wheat + Avena fatua & $188.7 \mathrm{~b}$ & $190.8 \mathrm{~b}$ \\
Wheat + Silybum marianum and & $174.3 \mathrm{c}$ & $176.3 \mathrm{c}$ \\
Avena fatua & & \\
LSD $_{0.05}$ & 8.75 & 8.62
\end{tabular}

\section{Conclusions and Recommendations}

Results showed that wheat in weed-free condition had maximum plant height, biomass, and leaf area index in both the growing season as compared to weeds ( $A$. fatua and $S$. Marianum) infested wheat. Reducing weed interference had a positive impact on biomass, and other growth parameters. The study indicated that $S$. marianum is a stronger competitor than $A$. fatua. Due to the large leaf canopy of $S$. marianum it is not possible for other species to sustain and the morphological mimicry of $A$. fatua with wheat crop during the vegetative growth stage, it cannot be easily distinguished from wheat seedlings. Hence it is recommended for farmers that timely management of both these noxious weeds specially $S$. marianum is very important to enhance the wheat yield.

\section{Novelty Statement}

In the past five decades the excessive use of herbicides is an alarming threat to the biodiversity and human health hazard. The present study describes weed suppression through enhancing crop density. This approach is an effective and eco-friendly weed management strategy to reduce the intended use of herbicides.

\section{Author's Contribution}

Ijaz Ahmad: Did research, collected data, analysis and wrote draft of the manuscript.

Bakhtiar Gul: Major supervisor who provided technical guidelines and supervised the whole Ph.D study.

\section{Conflict of interest}

The authors have declared no conflict of interest.

\section{References}

Abbas, R. 2010. Simulating the effect of Emex australis densities and sowing dates on agronomic traits of wheat. Pak. J. Agric. Sci., 47(2): 104-110.

Abdullah, G. Hassan, I.A. Khan, S.A. khan and H. Ali. 2008. Impact of planting methods and herbicides on weed biomass and some agronomic traits of maize. Pak. J. Weed Sci. Res., 14(3-4): 121-130.

Amanullah, M., J. Hassan, K. Nawab and A. Ali. 2007. Response of specific leaf area (SLA), leaf area index (LAI) and leaf area ratio (LAR) of maize (Zea mays) to plant density, rate and 
timing of nitrogen application. World Appl. Sci. J., 2(3): 235-243.

Anonymous, 2014. Pakistan economic survey. (http://www.finance. gov.pk/ survey_1415. html). Accessed on April 20, 2016.

Anonymous, 2016. Wheat production for 201516 was estimated at 25.45 million tons from an area of 9.17 million hectares. http://www. mnfsr.gov.pk/gop/index.php?

Blanco, A.M., G.R. Chantre, M.V. Lodovichi, J.A. Bandoni, R.L. Lopez, M.R. Vigna, R. Gigon and M.R. Sabbatini. 2014. Modelling seed dormancy release and germination for predicting Avena fatua L. field emergence: A genetic algorithm approach. Ecol. Model., 272: 293-300.

Bogale, A., K. Nefo and H. Seboka. 2011. Selection of some morphological traits of bread wheat that enhance the competitiveness against wild oat (Avena fatua). World J. Agric. Sci., 7(2): 128-135.

Darwent, L., D. Stevenson and P. Gamache. 2006. Canada thistle and perennial sow-thistle control in direct seeding systems. www.agric.gov.ab.ca Accessed on 10.01.2006.

Fakhari, R., A. Tobeh, P.S. Ziveh, G.D. Moghanlo, B.K. Tahmasbi. 2018. Effects of cover crop residue management on corn yield and weed control. J. Res. Weed Sci., 1: 7-17.

Gardner, F.P., R.B. Pearce, and R.L. Mitchell. 1985. Physiology of crop plants. Iowa state University Press. pp. 187-208.

Hassan, G. and K.B. Marwat. 2001. Integrated weed management in agricultural crops. Proc. National workshop on technologies for sustainable agriculture. NIAB, Faisalabad, Pakistan. pp. 27-34.

Hunt, R.H., 1990. Plant growth analysis. Unwin-Hyman, London. https://doi. org/10.1007/978-94-010-9117-6

Khaliq, A., A. Matloob, S. Mahmood, R.N. Abbas and M.B. Khan. 2012. Seeding density and herbicide tank mixtures furnish better weed control and improve growth, yield and quality of direct seeded fine rice. Int. J. Agric. Biol., 14: 499-508.

Khan, M.A., M. Abid, N. Hussain and T. Imran. 2004. Growth analysis of wheat (Triticum aestivum) cultivars under saline conditions. Int. J. Agri. Biol., 7(3): 508-510.

Khan, M.A., M. Abid, N. Hussain and T.
Imran.2005. Growth analysis of wheat (Triticum aestivum) Cultivars under saline conditions. Int. J. Agric. Biol., 7(3): 508-510.

Khan, I.A., G. Hassan, K.B. Marwat and I.A. Khattak. 2006. Yield and yield components of wheat affected by wild oats (Avena fatua L.) densities under irrigated conditions Herbologia, 7(2). 31-39.

Khan, I.A., G. Hassan, I. Daur and Abdullah. 2008. Competition of wild oats (Avena fatua L.) with different Wheat cultivars. Sarhad J. Agric., 24(1): 113-116.

Khan, I.A., G. Hassan, K.B. Marwat, S.M.A. Shah and S.A. Khan. 2010. Interaction of wild oats (Avena fatua L.) with divergent wheat cultivars. Pak. J. Bot., 42(2): 1051-1056.

Khan, I.A., G. Hassan, S.A. Khan and S.M.A. Shah. 2012. Wheat-wild oats interactions at varying densities and proportions. Pak. J. Bot., 44(3): 1053-1057.

Korres, N.E. and R.J. Froud-Williams. 2002.Effects of winter wheat cultivars and seed rate on the biological characteristics of naturally occurring weed flora. Weed Res., 42(6): 417e. https://doi. org/10.1046/j.1365-3180.2002.00302.x

Kumar, R., M.P. Singh and S. Kumar. 2012. Growth analysis of wheat (Triticum aestivum) Genotypes under saline condition. Int. J. Sci. Tech. Res., 1(6): 15-18.

Lehnhoff, E.A., Z.J.Miller, M.J Brelsford, S. White and B.D. Maxwell.2013. Relative canopy height influences wild oat (Avena fatua) seed viability, dormancy, and germination. Weed Sci., 61(4): 564-569. https://doi.org/10.1614/WS-D-1300084.1

Marwat, K.B., M.A. Khan, S. Hashim, K. Nawab and A.M. Khattak. 2011. Integrated weed management in wheat. Pak. J. Bot., 43(1): 625633.

Medek,D.E.,M.C.Ball and M.Schortemeyer.2007. Kwell publishing ltd relative contributions of leaf area ratio and net assimilation rate to change in growth rate depend on growth temperature: comparative analysis of subantarctic and alpine grasses. New Phytol., 175: 290-300. https:// doi.org/10.1111/j.1469-8137.2007.02097.x

Nassab, A.D.M. and F.S. Lalelo. 2012. Effect of density and root-shoot interference on wheat (triticum aestivumL.) And wild oat (Avena fatua) Performance. Int. Res. J. Appl. Basic Sci., 3(2): 279-285. 
O' Donovan, J.T., 1988. Wild oat infestations and economics returns as influenced by frequency of control. Weed Tech., 2: 495-498. https://doi. org/10.1017/S0890037X00032334

O’ Donovan, J.T., K.N. Harker, G.W. Clayton and L.M. Hall. 2000. Wild oat (Avena fatua) interference in barley (Hordeum vulgare) is influenced by barley variety and seeding rate. Weed Tech., 14(3): 624-629. https://doi. org/10.1614/0890-037X(2000)014[0624:WO AFII]2.0.CO;2

Scott, J.K., P.B. Yeoh and P.J. Michael. 2016. Methods to select areas to survey for biological control agents: An example based on growth in relation to temperature and distribution of the weed Conyza bonariensis. Biol. Cont., 97: 21-30.

Singh, V., H. Singh and A.S. Raghubanshi. 2013. Competitive interactions of wheat with Phalaris minor or Rumex dentatus: A replacement series study. Int. J. Pest Mgt., 59: 245-58.

Shaheen, K., M.A. Khan, A.A. Shad, K.B. Marwat and H. Khan. 2016. Temperature and salinity affect the germination and growth of Silybum marianum gaertn and Avena fatua L. Pak. J. Bot., 48: 469-476.

Umm-e-kulsoom and M.A. Khan. 2015. Prediction of grain yield losses in wheat (triticum aestivum L.) Under different densities of wild oat (Avena fatua). Pak. J. Bot., 47: 239-242.
Umm-E-Kulsoom., M.A. Khan, H.H. Ali, L. Ali, M.S. Rizwan, A. Mahmood, A. Raza and M.M. Javaid. 2020. Competitive interactions of wild oat (Avena fatua L.) with quality and yield of wheat (Triticum aestivum L.). Planta daninha, 38.

Weisany, W., S.Zehtab-Salmasi, Y. Raei, Y. Sohrabi and K.G. Golezani. 2016. Can arbuscular mycorrhizal fungi improve competitive ability of dill + common bean intercrops against weeds? Eur. J. Agron., 75: 60-71.

Watson, D.J., 1947. Comparative physiological studies on the growth of field crops: Variation in net assimilation rate and leaf area between species and varieties and within and between years. Ann. Bot. 11: 41-76. https://doi. org/10.1093/oxfordjournals.aob.a083148

Woldesenbet, A., A. Wolde and A. Tefera. 2016. Effects of wild oat (Avena fatua L.) Density on wheat (Triticum aestioum L.). Yield and yield components. Int. J. Res., 4(9): 124-130. https://doi.org/10.29121/granthaalayah. v4.i9.2016.2545

Ziaf, K., M. Amjad, M.A. Pervez, Q. Iqbal, I.A. Rajwana and M. Ayyub. 2009. Evaluation of different growth and physiological traits as indices of salt tolerance in hot pepper (Capsicum annuum). Pak. J. Bot., 41(4): 1797-1809. 